\title{
PENGEMBANGAN RUMAH TERHADAP PENINGKATAN SUHU RUANG AKIBAT BERKURANGNYA RUANG TERBUKA HIJAU
}

\author{
Muhammad Chaidar Febriansyah, Safruddin Juddah \\ Jurusan Teknik Arsitektur \\ Fakultas Sains dan Teknologi UIN Alauddin Makassar \\ Jl. Sultan Alauddin No. 63, Gowa, Sulawesi Selatan. 92113 \\ E-mail: Muhammad.chaidar@uin-alauddin.ac.id \\ Safruddin.juddah@uin-alauddin.ac.id
}

\begin{abstract}
Abstrak: Pertumbuhan masyarakat memicu peningkatan kebutuhan akan perumahan, seperti halnya Perumahan BTP saat ini. Pertumbuhan masyarakat di perumahan ini mendorong kebutuhan akan ruang yang lebih banyak di dalam hunian, dan seringkali warga mengembangkan rumah tanpa mengikuti aturan yang ada, sehingga mengubah ruang terbuka hijau menjadi ruang berlebih di dalam rumah. Penelitian ini bertujuan untuk menjelaskan besarnya pengurangan RTH di kawasan perumahan BTP blok AE yang dinilai dari luas pengembangan rumah. Penelitian ini menggunakan metode penelitian kuantitatif, dengan metode analisis yang digunakan adalah statistik deskriptif yang menggambarkan dan menjelaskan hasil penelitian. Analisis ini merupakan akumulasi dari data dasar berupa deskripsi. Pengumpulan data dilakukan dengan observasi langsung dan wawancara terstruktur menggunakan kuesioner. Hasil penelitian ditemukan bahwa $83 \%$ dari total sampel membangun rumah dengan luas $>81 \%$ dari lahan terbangun. Kemudian, $4 \%$ sampel dengan persentase luas tanah terbangun $71 \%-80 \%$, kemudian $11 \%$ sampel dengan persentase luas tanah terbangun $61 \%-70 \%$, dan selanjutnya $2 \%$ dari total luas sampel $51 \%-60 \%$ dari lahan terbangun. Kemudian 94\% sampel membangun rumah secara horizontal dengan luas 41 $\mathrm{m}^{2}-61 \mathrm{~m}^{2}$ dan $6 \%$ melakukan pembangunan horizontal seluas $20 \mathrm{~m}^{2}-40 \mathrm{~m}^{2}$ Sehingga hanya $6 \%$ dari total sampel yang masih dapat memanfaatkan RTH secara maksimal, dan 94\% tidak lagi dapat merasakan manfaat RTH dan mengakibatkan peningkatan suhu ruangan di dalam rumah.
\end{abstract}

Kata Kunci: renovasi rumah, ruang terbuka hijau, suhu ruangan

\section{PENDAHULUAN}

$\mathrm{P}$ ertumbuhan masyarakat saat ini memicu bertambahnya aspek pemenuhan kebutuhan manusia dari beragam sektor, begitu juga pada sektor kenyamanan dan kesejahteraan. Serupa dengan yang terjadi di kota Makassar, pemenuhan kebutuhan akan hunian seringkali memanfaatkan lingkungan alam secara berlebihan dan memberi dampak pada pengurangan ruang terbuka hijau yang cukup besar. Dalam arti, semakin bertambahnya penduduk di Kota Makassar maka semakin besar kebutuhan terhadap hunian dan secara tidak langsung, pemanfaatan lahan untuk pengembangan rumah akan semakin meningkat.

Penyediaan perumahan yang semakin besar, memberikan dampak terhadap pengurangan ruang terbuka hijau secara langsung maupun tidak langsung. Serupa yang 
terjadi di kawasan perumahan BTP saat ini, pertumbuhan penduduk pada kawasan ini memicu pengembangan hunian menjadi tidak terkendali.

Menurut Bramantyo et al. (2019), rendahnya mutu rumah pada perumahan subsidi terkait erat dengan keadaan fisik bangunan rumah serta prasarana umum yang disiapkan oleh pengembang. Kemudian, salah satu faktor dominan saat mengembangkan rumah adalah tingkat luas ruangan (Fahminnansih et al., 2010). Selaras dengan teori tersebut, masyarakat di perumahan BTP juga melakukan perluasan rumah guna memenuhi kebutuhan rumah tangga dan meningkatkan luas ruangan rumah. Tetapi, seringkali penghuni melakukan pengembangan rumah secara berlebihan, tanpa menyesuaikan dengan aturan yang ada.

Perumahan BTP Blok AE dibangun pada tahun 1989 dan peresmian pada awal tahun 1990, dengan mempunyai bentuk yang seragam (prototype) yaitu tipe 23, baik dari gubahan massanya maupun fisik ruangannya. Penelitian ini dilaksanakan karena melihat secara kasat mata jumlah ruang terbuka hijau pada kawasan perumahan BTP yang berkurang, seiring meningkatnya kegiatan pengembangan rumah. Sehingga diharapkan peneliti mampu menghitung dan mendeskripsikan pengurangan ruang terbuka hijau akibat pengembangan rumah pada Perumahan BTP blok AE.

\section{METODE PENELITIAN}

Jenis penelitian ini adalah penelitian kuantitatif. Menurut Kasiram dalam Kuntjojo (2009) dikatakan penelitian kuantitatif adalah suatu proses menemukan pengetahuan yang menggunakan data berupa angka sebagai alat menganalisis keterangan mengenai apa yang ingin diketahui Teknik analisis data yang digunakan adalah statistik deskriptif yang sifatnya memaparkan dan menjelaskan temuan hasil penelitian. Analisis ini berupa akumulasi data dasar dalam bentuk deskripsi (Muhson, 2009).

Penelitian ini dilakukan di Perumahan BTP blok AE Kota Makassar Provinsi Sulawesi Selatan dengan pertimbangan bahwa perumahan ini memiliki bentuk awal tipe rumah sederhana dengan beberapa rumah yang sudah melakukan pengembangan rumah ke arah horizontal. Perumahan BTP blok AE memiliki luas 18,3 Ha dengan pola permukiman berkelompok dan terarah, yang terbagi menjadi 3 RT yaitu RT 1 mempunyai luas area 5,5 Ha terdiri dari 227 unit rumah dan jumlah penduduk sebanyak 548 orang. Kemudian RT 2 mempunyai luas area 5,4 Ha terdiri dari 176 unit rumah dan jumlah penduduk sebanyak 325 orang, sedangkan RT 3 mempunyai luas area 7,4 Ha terdiri dari 135 unit rumah dan jumlah penduduk sebanyak 361 orang.

Objek penelitian adalah seluruh rumah tipe 23 yang sudah melakukan pengembangan rumah di Perumahan BTP Blok AE dan tidak sesuai dengan Koefisien Dasar Bangunan (KDB) yang diperbolehkan dalam Peraturan Menteri Negara Perumahan Rakyat No. 11 tahun 2008, yaitu intensitas lahan terbangun untuk rumah deret adalah 50\%. Rumah tipe 23 dipilih karena merupakan tipe rumah terkecil pada perumahan BTP dengan kegiatan renovasi terbesar yaitu $91 \%$ dari jumlah total populasi. 


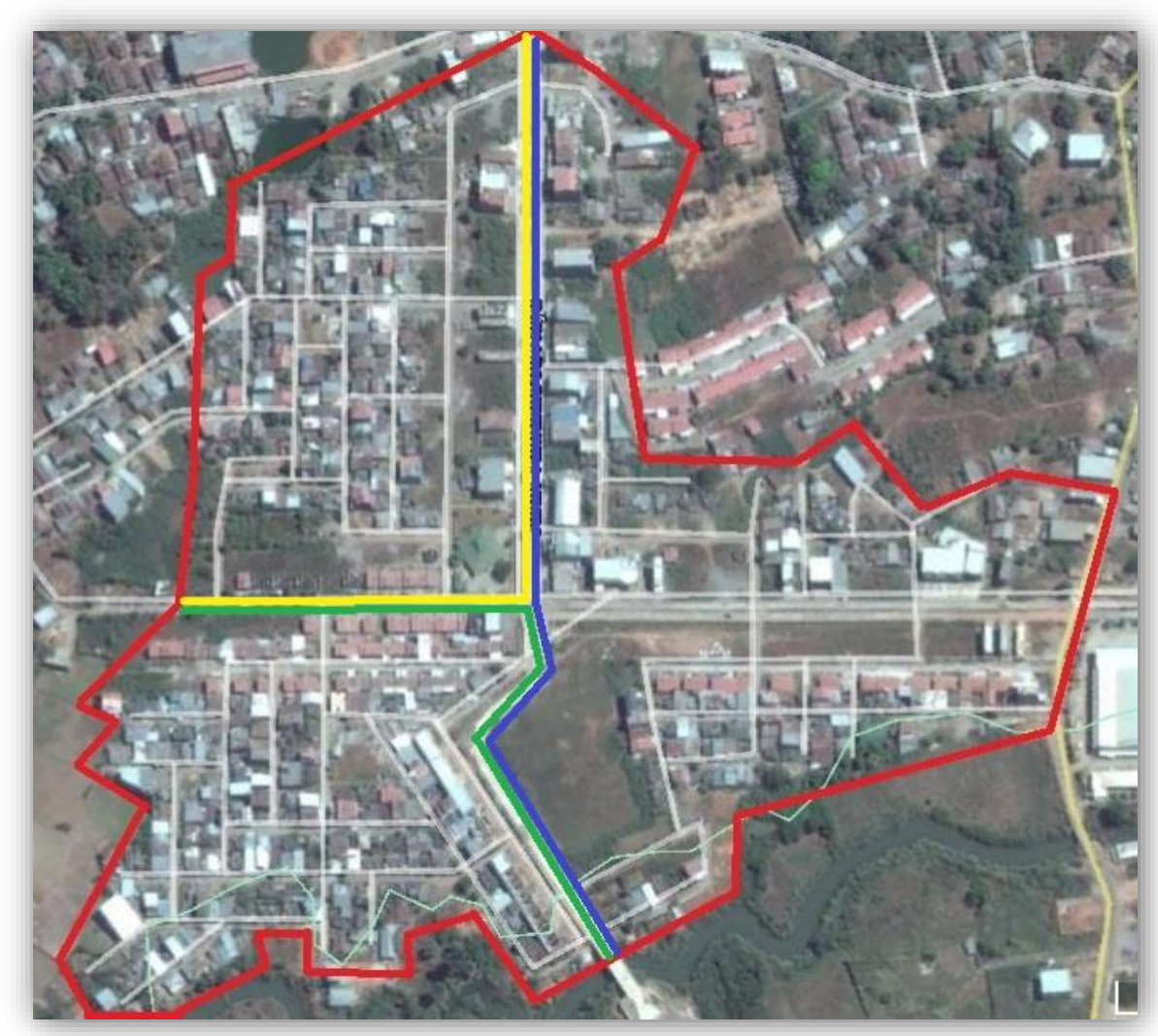

Gambar 1. Site Perumahan BTP blok AE

Proses pengambilan sampel menggunakan nonprobability dengan klasifikasi purpossive sampling, yaitu pengambilan sampel dengan pertimbangan tertentu (Sugiyono, 2007). Adapun pertimbangan penunjukan yaitu: (1) Rumah yang berpenghuni dan hak milik serta (2) Rumah yang sudah melakukan ekspansi.

Penentuan jumlah sampel yang diambil dalam penelitian ini ditentukan berdasarkan teori Gay \& Diehl dalam Gunawan (2017), yang berpendapat bahwa semakin banyak sampel yang diambil, maka akan semakin representatif dan hasilnya dapat digenelisir. Namun ukuran sampel bergantung pada jenis penelitiannya, yaitu:

1. Jika penelitiannya bersifat deskriptif, maka sampel minimumnya adalah $10 \%$ dari populasi;

2. Jika penelitiannya korelasional, sampel minimumnya adalah 30 subjek;

3. Apabila penelitian kausal perbandingan, sampelnya sebanyak 30 subjek perkelompok;

4. Apabila penelitian eksperimental, sampel minimumnya adalah 15 subjek perkelompok.

Berdasarkan teori tersebut, sesuai dengan jenis penelitian yang bersifat deskriptif, maka jumlah sampel adalah $10 \%$ dari jumlah populasi. Diketahui jumlah populasi Perumahan BTP blok AE adalah 538 rumah, jika dibagi 10\%, maka jumlah sampel yang dibutuhkan yaitu 53,8 atau dibulatkan menjadi 54 sampel rumah. Responden atau narasumber ditujukan kepada kepala keluarga sebagai satuan terkecil dalam rumah guna mendapatkan gambaran dan informasi mengenai ekspansi rumah yang dihuni.

Cara yang digunakan dalam proses pengumpulan data adalah:

1. Observasi langsung dengan membuat catatan, sketsa dan mengambil gambar rumah.

2. Teknik wawancara dengan mengajukan beberapa pertanyaan yang telah disiapkan.

3. Pengumpulan dokumen berbentuk tulisan, gambar, atau sejarah dari objek penelitian. 
Data yang telah diperoleh di lapangan kemudian dianalisis dengan menggunakan tiga cara, yaitu:

1. Reduksi data, mengumpulkan, memilih dan menyederhanakan data yang diperoleh di lapangan.

2. Penyajian data dengan menggunakan tabel dan teks naratif sehingga dapat diperoleh kesimpulan yang dibutuhkan. Kesimpulan, merupakan proses untuk menjawab permasalahan dan tujuan sehingga dapat diberikan masukan untuk memecahkan masalah.

\section{HASIL DAN PEMBAHASAN}

Seperti yang tercantum pada Pasal 12 dalam Peraturan Menteri Negara Perumahan Rakyat (2008) bahwa intensitas lahan tutupan untuk rumah deret adalah 50\%. Pada awal pembangunan perumahan BTP blok AE, pengembang membangun rumah deret dengan masing-masing luas kavling sebesar $84 \mathrm{~m}^{2}$ dengan luas lahan terbangun adalah $23 \mathrm{~m}^{2}$ atau $27 \%$ dan luas ruang terbuka sebesar $61 \mathrm{~m}^{2}$ atau $73 \%$ dari total luas kavling.

Tabel 1. Persentase luas lahan terbangun

\begin{tabular}{lcc}
\hline Lahan Terbangun $(\boldsymbol{\%})$ & $\mathbf{n}$ & $\mathbf{\%}$ \\
\hline$<50$ & - & - \\
$51-60$ & 1 & 2 \\
$61-70$ & 6 & 11 \\
$71-80$ & 2 & 4 \\
$>81$ & 45 & 83 \\
Total & 54 & 100 \\
\hline
\end{tabular}

Sumber: Hasil Analisis, 2015

Seiring dengan aktivitas pengembangan rumah yang dilakukan oleh penghuni, lahan terbangun yang awal pembangunan sesuai dengan arahan pemerintah, yaitu 50\% lahan terbangun, saat ini sudah berkembang dan menjadi tidak sesuai dengan arahan pemerintah. Terlihat pada Tabel 1 bahwa, 83\% dari total sampel melakukan pengembang rumah dengan lahan terbangun $>81 \%$. Kemudian, $4 \%$ sampel dengan $71 \%-80 \%$ luas lahan terbangun, dan selanjutnya $11 \%$ sampel dengan luas lahan terbangun sebesar $61 \%$ - 70\%, dan kemudian 2\% dari total sampel seluas 51\% - 60\% lahan terbangun. Hal ini menunjukkan bahwa tidak ada dari keseluruhan sampel, mempunyai intensitas lahan tutupan yang masih sesuai dengan arahan pemerintah.

Menurut Agusniansyah \& Widiastuti (2016), pengembangan rumah horizontal adalah rumah yang berkembang ke arah depan, samping dan belakang. Pada umumnya, penghuni di perumahan BTP blok AE melakukan pengembangan rumah secara horizontal seperti yang terlihat pada Tabel 2 .

Tabel 2. Persentase luas pengembangan rumah ke arah horizontal

\begin{tabular}{lcc}
\hline Luas Pengembangan Rumah & n & \% \\
\hline$<19 \mathrm{~m}^{2}$ & - & - \\
$20 \mathrm{~m}^{2}-40 \mathrm{~m}^{2}$ & 3 & 6 \\
$41 \mathrm{~m}^{2}-61 \mathrm{~m}^{2}$ & 51 & 94 \\
Total & 54 & 100 \\
\hline
\end{tabular}

Sumber: Hasil Analisis, 2015 
Pada Tabel 2 tampak bahwa 94\% dari sampel rumah lebih memilih untuk melakukan pengembangan rumah secara horizontal. Awalnya rumah hanya memiliki luas $23 \mathrm{~m}^{2}$, kemudian penghuni melakukan pengembangan rumah seluas $41 \mathrm{~m}^{2}-61 \mathrm{~m}^{2}$, dan pengembangan rumah dengan luas $20 \mathrm{~m}^{2}-40 \mathrm{~m}^{2}$ sejumlah $6 \%$. Sedangkan, luas pengembangan rumah ke arah horizontal yang diperbolehkan untuk Perumahan BTP blok AE hanya seluas $19 \mathrm{~m}^{2}$.
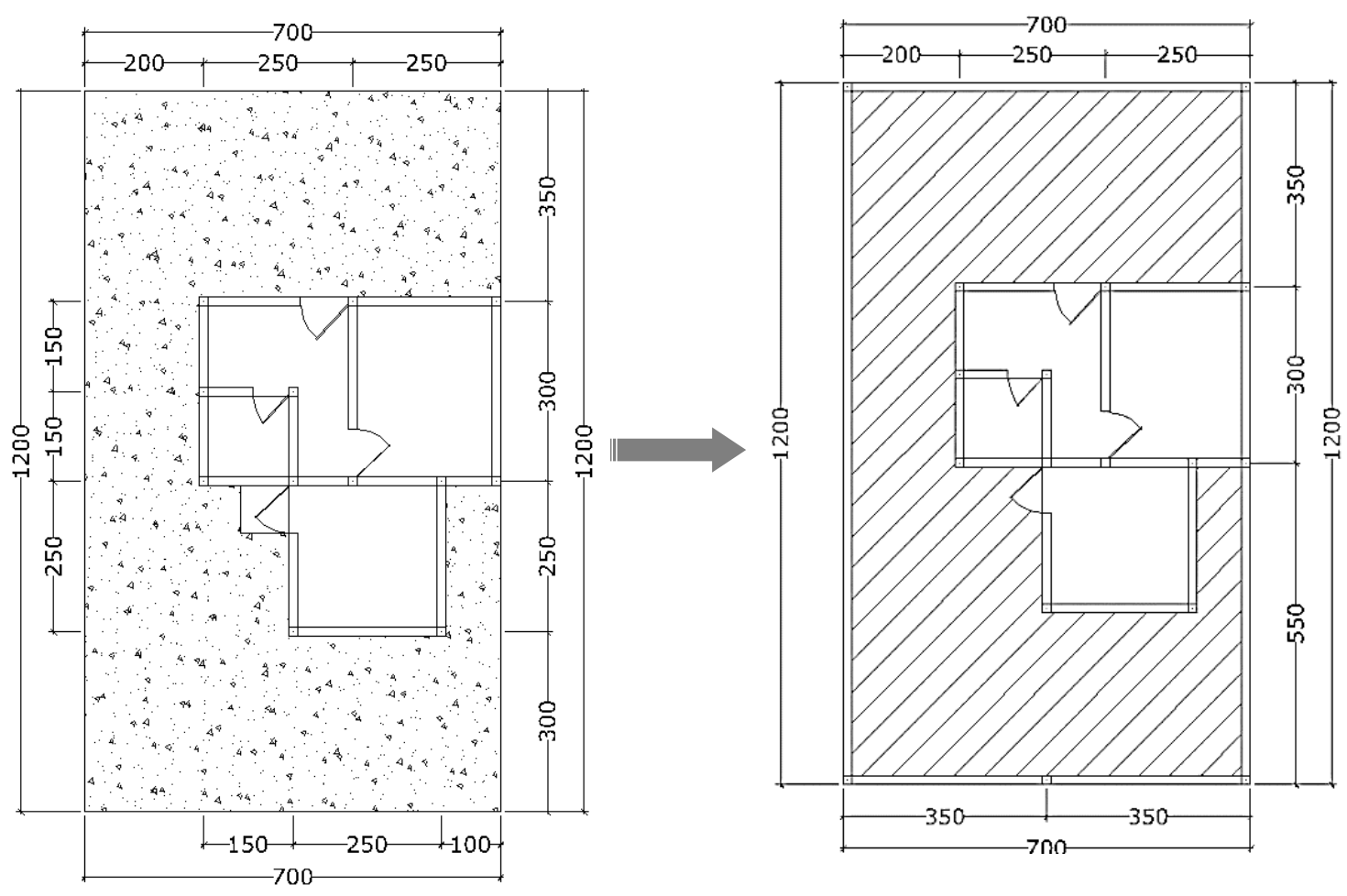

Gambar 2. Ilustrasi perubahan luas pengembangan rumah

Terlihat pada Gambar 2 mengenai ilustrasi perubahan luas pengembangan rumah secara horizontal, dengan menutupi seluruh lahan pada kavling dengan luas pengembangan sebesar $61 \mathrm{~m}^{2}$.

Menurut Syamsu (2017), peningkatan jumlah penduduk yang disebabkan oleh kelahiran ataupun urbanisasi serta peningkatan pembangunan sarana dan prasarana kota mengakibatkan berkurangnya peruntukan lahan sebagai ruang terbuka sehingga berdampak juga pada kurangnya penyediaan lahan untuk ruang terbuka hijau. Penyediaan RTH privat pada kawasan terbangun berupa hunian seperti yang tercantum dalam Peraturan Menteri Negara Perumahan Rakyat (2008) adalah seluas 8\% untuk setiap hunian. Terkait peraturan tersebut, setiap pengembang dan penghuni harus mamatuhi aturan yang ditetapkan dalam pembangunan atau pengembangan rumah

Pengembang yang membangun Perumahan BTP blok AE awalnya menyediakan ruang terbuka yang mampu dimanfaatkan oleh penghuni untuk membuat RTH privat pada setiap hunian seluas $61 \mathrm{~m}^{2}$ atau $73 \%$ dari luas masing-masing kavling. Akan tetapi, yang terjadi saat ini, seperti yang terlihat pada tabel Ruang terbuka Hijau privat berdasarkan lahan terbangun yang ditunjukkan pada Tabel 3. 
Febriansyah \& Juddah., Pengembangan Rumah ..._ 300

Tabel 3. Luas ruang terbuka hijau privat berdasarkan lahan terbangun

\begin{tabular}{llllllll}
\hline \multirow{2}{*}{ RTH Privat } & \multicolumn{4}{c}{ Lahan Terbangun } & \multicolumn{3}{c}{ Total } \\
\cline { 2 - 9 } & $<\mathbf{5 0}$ & $\mathbf{5 1 - 6 0}$ & $\mathbf{6 1 - 7 0}$ & $\mathbf{7 1 - 8 0}$ & $>\mathbf{8 1}$ & $\mathbf{n}$ & $\mathbf{\%}$ \\
\hline$>8 \%$ & - & - & 3 & - & - & 3 & 6 \\
$<7 \%$ & - & 1 & 3 & 2 & 45 & 51 & 94 \\
Total & - & 1 & 6 & 2 & 45 & 54 & 100 \\
\hline
\end{tabular}

Sumber: Hasil Analisis, 2015

Tabel 3 menunjukkan bahwa sejumlah 94\% sampel tidak memiliki RTH privat yang sesuai dengan Pedoman Penyediaan Dan Pemanfaatan Ruang Terbuka Hijau di Kawasan Perkotaan (2008). Sementara itu, hanya 6\% sampel yang masih menyediakan RTH privat $>8 \%$. Hal ini sangat bepengaruh pada peningkatan suhu panas di dalam rumah. Karena selain berfungsi sebagai penyaring udara kotor dan konservasi air tanah, Ruang Terbuka Hijau juga berfungsi untuk mengurangi suhu panas (Muhtadi, 2017).

Kegiatan pengembang rumah yang dilakukan oleh 54 sampel pada kawasan Perumahan BTP blok AE, secara langsung maupun tidak langsung menyebabkan berkurangnya ruang terbuka hijau yang disediakan oleh pengembang pada awal pembangunan. $6 \%$ sampel mampu memanfaatkan ruang terbuka hijau yang disediakan menjadi RTH privat yang sesuai dengan Pedoman Penyediaan dan Pemanfaatan Ruang Terbuka Hijau di Kawasan Perkotaan (2008). Sedangkan, 94\% tidak mampu memanfaatkan ruang terbuka yang disediakan menjadi RTH privat.

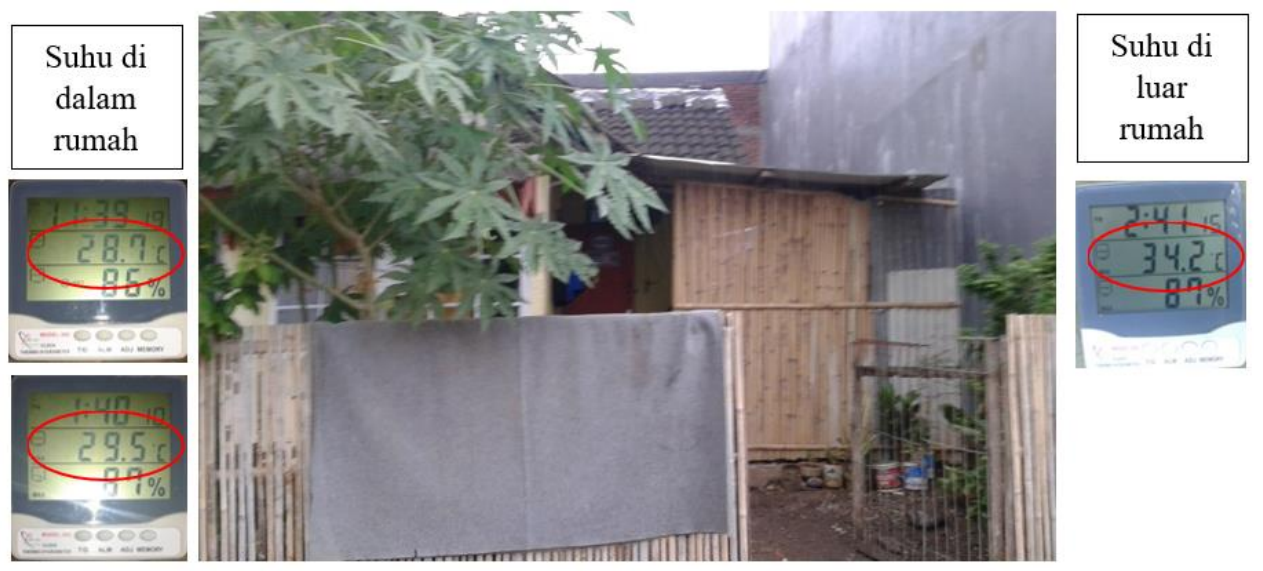

Gambar 3. Perbandingan suhu di dalam dan di luar rumah yang masih memiliki ruang terbuka hijau $>8 \%$

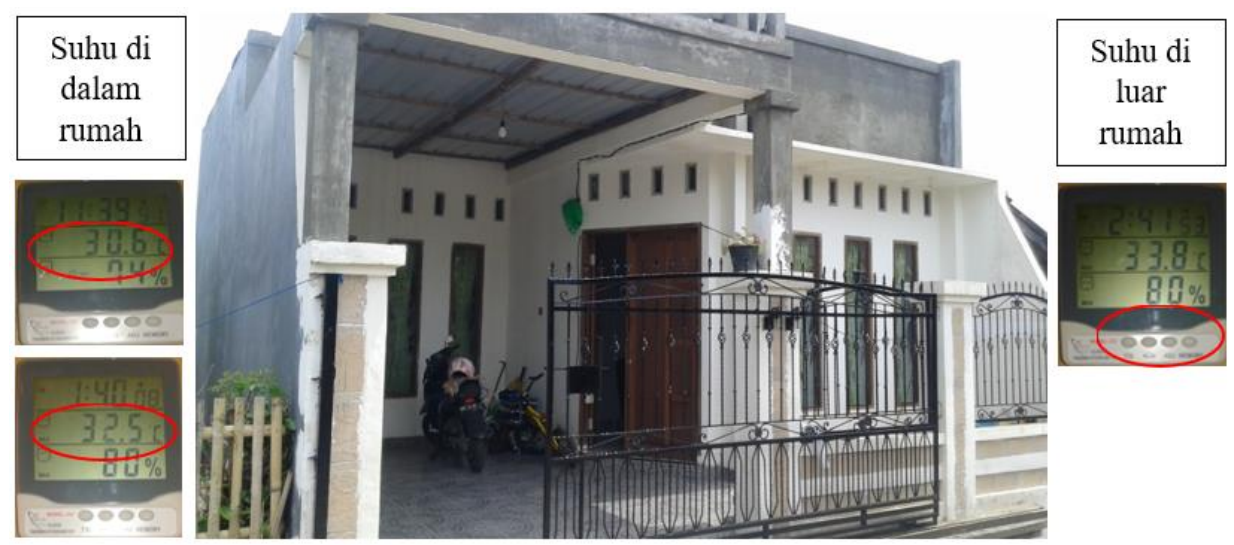

Gambar 4. Perbandingan suhu di dalam dan di luar rumah yang masih memiliki ruang terbuka hijau $<8 \%$ 
Terlihat pada Gambar 3 dan 4 serta Tabel 4 bahwa, suhu ruang dalam rumah yang memiliki RTH $>8 \%$ lebih rendah yaitu $28,7^{\circ} \mathrm{C}-29,5^{\circ} \mathrm{C}$ dengan perbandingan suhu luar $34,2^{\circ} \mathrm{C}$, sedangkan suhu ruang rumah yang memiliki RTH $<8 \%$ lebih tinggi yaitu $30,6^{\circ} \mathrm{C}$ $-32,5^{\circ} \mathrm{C}$ dengan perbandingan suhu luar $33,8^{\circ} \mathrm{C}$.

Tabel 4. Perbandingan suhu ruang dalam rumah dan luar rumah

\begin{tabular}{clc}
\hline \multirow{2}{*}{ RTH Privat } & \multicolumn{2}{c}{ Suhu Ruang } \\
\cline { 2 - 3 } & Suhu Ruang Dalam Rumah & Suhu Ruang Luar Rumah \\
\hline$>8 \%$ & $28,7^{\circ} \mathrm{C}-29,5^{\circ} \mathrm{C}$ & $34,2^{\circ} \mathrm{C}$ \\
$<8 \%$ & $30,6^{\circ} \mathrm{C}-32,5^{\circ} \mathrm{C}$ & $33,8^{\circ} \mathrm{C}$ \\
\hline
\end{tabular}

Sumber: Hasil Analisis, 2015

\section{KESIMPULAN}

Berdasarkan hasil analisis mengenai dampak pengembangan rumah yang mengakibatkan berkurangnya Ruang Terbuka Hijau privat pada perumahan BTP blok AE, maka dapat disimpulkan bahwa 94\% dari sampel rumah lebih memilih untuk melakukan pengembangan rumah secara horizontal dengan penambahan pengembangan rumah seluas $41 \mathrm{~m}^{2}-61 \mathrm{~m}^{2}$. Sehingga, 94\% sampel memiliki peningkatan suhu pada ruang rumah mereka yang disebabkan oleh suhu panas matahari yang tidak bisa di reduksi oleh vegetasi pada Ruang Terbuka Hijau privat.

\section{DAFTAR PUSTAKA}

Agusniansyah, N., \& Widiastuti, K. (2016). Konsep pengolahan desain rumah tumbuh. Modul, 16(1), 1-12. https://doi.org/10.14710/mdl.16.1.2016.1-12.

Bramantyo, Tyas, W. P., \& Argyantoro, A. (2019). Aspek kualitas rumah subsidi pada program rumah murah berdasarkan perspektif penerima manfaat studi kasus: Perumahan subsidi Mutiara Hati Semarang. Jurnal Permukiman, 14(1), 1-9.

Fahminnansih, F., R. Indryani., \& N. Iriawan(2010). Studi penentuan faktor-faktor pengaruh tingkat kecenderungan renovasi rumah di perumahan dengan menggunakan analisis survival. Prosiding Seminar Nasional Manajemen Teknologi XII Program Studi MMT-ITS, 1-10.

Gunawan, C. M. (2017). Studi komparatif pengaruh perubahan tampilan visual desain interior gerai coach terhadap minat beli konsumen di Surabaya. Jurnal INTRA, 5(1), 41-48.

Kuntjojo. (2009). Metodologi Penelitian. Kediri: Universitas Nusantara PGRI.

Muhson, A. (2009). Pengembangan Metodologi Penelitian dan Sistematika Penulisan. Yogyakarta: Universitas Yogyakarta.

Muhtadi, A. (2017). Analisis Ruang Terbuka Hijau di Kota Mempawah. Tanjungpura: Fakultas Teknik Universitas Tanjungpura.

Peraturan Menteri Negara Perumahan Rakyat. (2008). Peraturan Menteri Negara Perumahan Rakyat Nomor: 11/Permen/M/2008 Pedoman Keserasian Kawasan Perumahan dan Permukiman.

Sugiyono. (2007). Statistik Untuk Penelitian. Bandung: Penerbit Alfabeta.

Syamsu, R. (2017). Kebutuhan ruang terbuka hijau di kota Makassar. Jurnal Hutan dan Masyarakat, 3(April), 65-77.

Departemen Pekerjaan Umum. (2008). Pedoman Penyediaan dan Pemanfaatan Ruang Terbuka Hijau di Kawasan Perkotaan. Jakarta: Departemen Pekerjaan Umum. 